\title{
Enhancing Teacher-Student Interaction and Students' Engagement in a Flipped Translation Classroom
}

\author{
Yi Wei* \\ Foreign Languages Department, Shijiazhuang Tiedao University, Shijiazhuang, China
}

\section{OPEN ACCESS}

Edited by:

Ali Derakhshan,

Golestan University, Iran

Reviewed by:

Fei Xie,

Henan University, China Liqaa Habeb Al-Obaydi,

University of Diyala, Iraq

${ }^{*}$ Correspondence:

Yi Wei

weiyi83@stdu.edu.cn

Specialty section:

This article was submitted to

Educational Psychology,

a section of the journal

Frontiers in Psychology

Received: 25 August 2021 Accepted: 01 September 2021 Published: 05 October 2021

Citation:

Wei Y (2021) Enhancing Teacher-Student Interaction and Students' Engagement in a Flipped

Translation Classroom.

Front. Psychol. 12:764370. doi: 10.3389/fpsyg.2021.764370
Learning faculties are looking for innovative approaches to effective teaching in the translation process which can not only enhance students' engagement but increase the interactions between teacher and learners as well. With the amplified accessibility of network-centered instructive knowledge, teaching translation from the viewpoint of computer-aided instructions and online platforms have flourished. Flipped classroom (FC) is one of these new inclinations used in higher education nowadays which can attract stakeholders' attention. This review aims at exploring its effects on students' engagement and teacher-student interaction in translation classes. Some implications and suggestions have been presented for language teaching stakeholders in translation research.

Keywords: innovative approaches, flipped translation classroom, students' engagement, teacher-student interaction, translation research

\section{INTRODUCTION}

There are currently remarkable issues about the translation courses, according to the surveys done in universities and colleges (Gong and $\mathrm{Du}, 2019)$. Students regularly deal with some problems including low achievement, lack of enthusiasm, engagement, and self-confidence (Joyce, 2018; Sun and Yuan, 2018). Significantly, translation instruction essentially follows the conventional mode, involving excessive education, insufficient class hours, inability to internalize translation theory, difficulty in shaping abilities, and inability to exercise translation thinking (Gong and Du, 2019). Since it is affected by the conventional educational model, the English translation course needs new educational ideas and approaches since their absence has truly blocked its improvement. Thus, changing the educational method of translation is a significant point, and it turned into a recent trend with the improvement of network innovation (Liu and Zhou, 2019). Indeed, being affected by conventional teaching, the progress of translation is hindered, so innovative teaching approaches in English translation courses should be accentuated (Wenwen and Yuying, 2020).

There are some different ways to assist learners to overcome these difficulties, one of which is to apply a learning method that is proper to solve the problems that learners generally come across in translation classes (Mannahali and Rijal, 2020). A method that has newly become popular in education is flipped classroom (FC) (Akcayir and Akcayir, 2018). In FC, teachers give learners asynchronous video speeches as assignments, thereby creating more opportunities for intuitive exercises in the class (Jensen et al., 2018). In addition, Bergmann and Sams (2012) have depicted the FC approach in a more extensive viewpoint, and they maintain that the FC approach is a setting 
where students take charge of their own education which per se builds connections among learners and educators. In FC, students' responsibility for the content is promoted inasmuch as the fact assignments are utilized in a way to help learners to find thoughts and ideas on their own (Strayer et al., 2016).

Likewise, exploratory tasks and class negotiations often happen in cooperative groups that consequently stimulating constructive peer-to-peer communications and augment teacher-student interpersonal communications (Xie and Derakhshan, 2021) that is considered as vehicles for increasing student engagement (Derakhshan, 2021). The positive relation between teacher and student is a facilitator of an extensive kind of proper learner-related consequences including engagement, success, and enthusiasm (Derakhshan et al., 2019; Pishghadam et al., 2021).

Among various factors, one justification for the interest in the FC could be the significant role of learners' engagement (Zainuddin and Halili, 2016) that has been at the center of attention lately due to the arrival of positive psychology (Wang et al., 2021). Student engagement is considered as a causative issue in education nowadays that refers to the strength and energy that students employ in the progress of their learning and it is manifested through the ranges of behavioral, cognitive, or affective criteria (Li, 2021). To preserve student engagement, another effective factor is the mutual relation between teacher and student (Pianta et al., 2012).

Indeed, FC has shifted the rights of learning from teachers to students (Sohrabi and Iraj, 2016) that cultivate autonomy. Learners learn via active learning practices that enhance their engagement and increase their critical thinking (Baepler et al., 2014). A major contribution of flipped education for many educators is the chance to involve learners in various learning activities in an environment where they, as well as the learners' classmates, are available to assist and cooperate (Hodgson et al., 2017). It is also important to note that changes have also occurred in the responsibilities and duties of learners; knowledge is no longer received passively by learners. Instead, they become active participants in classroom discussions through educators' guidance (Yanhui and Yi, 2014).

In the classroom, a major shortcoming of the translation classes is that learners do not receive the educators prompt attention during the initial stages of absorbing and internalizing knowledge, which can act as an obstacle in this process (Yu, 2017). As the FC concurs with the hypothesis of constructivism (Bada and Olusegun, 2015), this issue can be settled in which translation education becomes like the fundamental scholarly translation knowledge, and translation procedures can be introduced before the class time to save time for learners to take on information through individual questions and shared learning, and subsequently study and merge information they have learned through the classroom communication (Yukun and Aili, 2014). The goal of a flipped translation education is unique in comparison to a conventional translation class where most of the class time is allotted to addressing translation procedures and working on translation assignments. The objective of FC for learners is to foster autonomy in learning translation and to utilize higher-order thinking to expand their translation ability (Lin, 2019).

On the one hand, the impact of the FC on learners' engagement and academic success are scrutinized in prior studies (Jamaludin and Osman, 2014; Jensen et al., 2018), and on the other hand, peer-peer and learner-educator communication were investigated in some other studies (McLean et al., 2016); however, to date, no FC researches had been carried out relating the abovementioned issues in translation classroom. Therefore, this review aims to address the aforementioned gap, by considering the same issue in the translation classroom.

\section{FLIPPED CLASSROOMS AND ITS ADVANTAGES}

FC idea allows learners to study the material in advance, so teachers devoted class time for collaborative discussions (Rotellar and Cain, 2016). There have been many perspectives and observations about the success of FC instruction, as its popularity grows every year (Hall and DuFrene, 2016). One of its advantages is an increase in the efficiency of time management as FC usually involves watching a video version of the course material online as an assignment. So, students have the opportunity to be actively engaged in that material during class the following day (Martin and Rimm-Kaufman, 2015). Likewise, it permits educators to invest more energy in communicating with learners, which sets out more open doors to check for comprehension and clear up misguided judgments (Bergmann and Sams, 2012). Learners acquire information at home in a flipped approach through watching video slides prepared by the educator and practicing the abilities in class, where the educator can definitely regulate and manage the student (Chen Hsieh et al., 2017). Undoubtedly, as declared by Hung (2015), the learners' arrangement before the class is vital for them to have the option to be more included and to accomplish additional satisfying results. The principle of flipped learning is to involve learners through active learning conditions intended to prepare and rouse them to carry out appraisal assignments because of feedback presented via interaction through all the phases of learning.

The flipped approach intends to establish a learner-focused learning climate in which learners deal with their own learning and become more dynamic and intuitive in class which stimulates higher-order thinking, and improves educator-learner collaborations (Zainuddin, 2018). The flipped approach offers priority to learners where they are all involved in their learning and the educator turns into the "guide on the side" (Baker, 2000 as cited in Suo and Hou, 2017). Concerning the active learning in FC, one could argue that the classroom activities in such classes lead to a positive learning context, which increases students' levels of involvement and engagement (Jamaludin and Osman, 2014). Furthermore, engaging learners in problem-solving boosts their connections and confidence for their own educations, leading to higher emotional involvement (Lin, 2017, 2019), and at the same time, students' intellectual engagement increases when they have the option to ask questions that determines the 
influence of flipped classroom on student interaction (Schussler, 2009).

\section{IMPLICATIONS AND FUTURE DIRECTIONS}

The present review probes into the role of FC in translation teaching and its effect on students' engagement as well as the student and teacher interactions. The present review has noteworthy implications for teaching translation. Indeed, by implementing FC in translation classrooms, students are encouraged to interact more and improve communication between educators and learners (Cen, 2018). So, to encourage learners to participate, the teacher provides useful video lectures for learners in advance to make them for discussion (Zainuddin and Perera, 2019). The teacher should provide problem-solving tasks for the learners as these types of tasks aim to engage students in the class discussion and develop their accountability for learning and help students become autonomous and problem solvers (Huang and Napier, 2015) and the activities should be designed in a way to trigger teacher-student interaction in class leading to the cultivation of critical thinking and creativity (Munir et al., 2018). The interaction embedded in FC can bring about more confidence (Cakici and Oflaz, 2012; Xie and Derakhshan, 2021) and provides the opportunity for more practice that impacts their enthusiasm and engagement (Kim and Kim, 2014; Derakhshan, 2021). In addition, the syllabus

\section{REFERENCES}

Akcayir, G., and Akcayir, M. (2018). The flipped classroom: a review of its advantages and challenges. Comput. Educ. 126, 334-345. doi: 10.1016/j.compedu.2018.07.021

Bada, S. O., and Olusegun, S. (2015). Constructivism learning theory: a paradigm for teaching and learning. J. Res. Method Educ. 5, 66-70.

Baepler, P., Walker, J. D., and Driessen, M. (2014). It's not about seat time: blending, flipping, and efficiency in active learning classrooms. Comput. Educ. 78, 227-236. doi: 10.1016/j.compedu.2014.06.006

Bergmann, J., and Sams, A. (2012). Before you flip, consider this. Phi Delta Kappan 94, 25-25. doi: 10.1177/003172171209400206

Cakici, D., and Oflaz, A. (2012). "Language learning strategies used by prospective teachers at English and German language teaching departments," in The 3rd Black Sea ELT Conference: Technology: A Bridge to Knowledge Learning, Samsun, Turkey, November,37,1-12.

Cen, H. (2018). "The application of flipped classroom model in college English translation teaching," in Asia-Pacific Social Science and Modern Education Conference (SSME 2018). Paris: Atlantis Press, 80-83. doi: 10.2991/ssme-18.2018.14

Chen Hsieh, J. S., Wu, W. C. V., and Marek, M. W. (2017). Using the flipped classroom to enhance EFL learning. Comput. Assist. Lang. Learn. 30, 1-21. doi: 10.1080/09588221.2015.1111910

Derakhshan, A. (2021). The predictability of Turkman students' academic engagement through Persian language teachers' nonverbal immediacy and credibility. J. Teach. Persian Speakers Other Lang. 10, 3-26.

Derakhshan, A., Saeidi, M., and Beheshti, F. (2019). The interplay between Iranian EFL teachers' conceptions of intelligence, care, feedback, and students' stroke. IUP J. English Stud. 14, 81-98.

Gong, Y., and Du, X. (2019). An empirical study on the teaching of traditional Chinese medicine translation based on reversal classroom. 3rd International Conference on Education Technology and Economic Management (ICETEM 2019). designers should design class activities in a way that activates the teacher and student interaction since it was a policy for them to share knowledge with peers and their teacher that promote their engagement (Zainuddin and Attaran, 2016). As principle and practice should be closely associated, translation educators are supposed to apply FC in practices in the process of teaching and instruction to enhance students' engagement and interaction. In particular, in the time of pandemic worldwide, EFL teachers who teach translation courses should adapt to this new online teaching as well focus on EFL learners' adaptation to flipped learning style. As a result, future experimental studies can be conducted to assure the effect of FC.

\section{AUTHOR CONTRIBUTIONS}

The author confirms being the sole contributor of this work and has approved it for publication.

\section{FUNDING}

This study was sponsored by Research of the Translation Course Reform of English Major against the Background of Constructing the Discourse System of China's Engineering Technology of Research and Practice Project of Teaching Reform of Higher Education of Hebei Province (Approval No. 2018GJJG231).
Hall, A. A., and DuFrene, D. D. (2016). Best practices for launching a flipped classroom. Bus. Profess. Commun. Q. 79, 234-242. doi: $10.1177 / 2329490615606733$

Hodgson, T. R., Cunningham, A., McGee, D., Kinne, L., and Murphy, T. J. (2017). Assessing behavioral engagement in flipped and non-flipped mathematics classrooms: teacher abilities and other potential factors. Int. J. Educ. Math. Sci. Technol. 5, 248-261. doi: 10.18404/ijemst.296538

Huang, Z., and Napier, J. (2015). Perceptions of teachers and students on the qualities of an effective translation teacher. J. Lang. Learn. Teach. 5, $1-23$.

Hung, H. T. (2015). Flipping the classroom for English language learners to foster active learning. Comput. Assist. Lang. Learn. 28, 81-96. doi: 10.1080/09588221.2014.967701

Jamaludin, R., and Osman, S. Z. (2014). The use of a flipped classroom to enhance engagement and promote active learning. J. Educ. Pract. 5, 124-131.

Jensen, J., Holt, E., Sowards, J., Heath Ogden, T., and West, R. (2018). Investigating strategies for pre-class content learning in a flipped classroom. J. Sci. Educ. Technol. 27, 523-535. doi: 10.1007/s10956-018-9740-6

Joyce, P. (2018). L2 vocabulary learning and testing: The use of L1 translation versus L2 definition. Lang. Learn. J. 46, 217-227. doi: 10.1080/09571736.2015.1028088

Kim, B. H., and Kim, B. H. (2014). Korean language culture and discussion class? Role-exchange discussion class based on flipped learning. J. Korean Lang. Stud. 37,141-166. doi: 10.18110/urimal.2014..37.141

$\mathrm{Li}$, R. (2021). The role of teacher-student interpersonal relations in flipped learning on student engagement. Front. Psychol.. 12:741810. doi: 10.3389/fpsyg.2021.741810

Lin, W. (2017). On interactive teaching model of translation course based on Wechat. English Lang. Teach. 10, 21-25. doi: 10.5539/elt.v10n3p21

Lin, Y. T. (2019). Cooperative experiential learning in a flipped translation classroom. Int. J. English Ling. 9, 29-36. doi: 10.5539/ijel.v9n5p29

Liu, Y., and Zhou, X. (2019). "The construction of flipped classroom teaching mode in college English translation teaching," in 5th International Conference on Arts, 
Design and Contemporary Education (ICADCE 2019) (New York, NY: Atlantis Press), 592-594. doi: 10.2991/icadce-19.2019.125

Mannahali, M., and Rijal, S. (2020). Communicative translation method in increasing students' performance in translation class. Asian ESP J. 16, 259-270. http://eprints.unm.ac.id/id/eprint/18445

Martin, D. P., and Rimm-Kaufman, S. E. (2015). Do student self-efficacy and teacher-student interaction quality contribute to emotional and social engagement in fifth-grade math? J. Sch. Psychol., 53, 359-373. doi: 10.1016/j.jsp.2015.07.001

McLean, S., Attardi, S., Faden, L., and Goldszmidt, M. (2016). Flipped classrooms and student learning: not just surface gains. Adv. Physiol. Educ. 40, 47-55. doi: 10.1152/advan.00098.2015

Munir, M. T., Baroutian, S., Young, B. R., and Carter, S. (2018). Flipped classroom with cooperative learning as a cornerstone. Educ. Chem. Eng. 23, 25-33. doi: 10.1016/j.ece.2018.05.001

Pianta, R. C., Hamre, B. K., and Allen, J. P. (2012). “Teacher-student relationships and engagement: Conceptualizing, measuring, and improving the capacity of classroom interactions," in Handbook of Research on Student Engagement, eds S. L. Christenson, A. L. Reschly, and C. Wylie (Boston, MA: Springer), 365-386. doi: 10.1007/978-1-4614-2018-7_17

Pishghadam, R., Derakhshan, A., Zhaleh, K., and Habeb Al-Obaydi, L. (2021). Students' willingness to attend EFL classes with respect to teachers' credibility, stroke, and success: a cross-cultural study of Iranian and Iraqi students' perceptions. Curr. Psychol. doi: 10.1007/s12144-021-01738-z. [Epub ahead of print].

Rotellar, C., and Cain, J. (2016). Research, perspectives, and recommendations on implementing the flipped classroom. Am. J. Pharm. Educ. 80, 1-9. doi: 10.5688/ajpe80234

Schussler, D. L. (2009). Beyond content: how teachers manage classrooms to facilitate intellectual engagement for disengaged students. Theory Pract. 48, 114-121. doi: 10.1080/00405840902776376

Sohrabi, B., and Iraj, H. (2016). Implementing flipped classroom using digital media: a comparison of two demographically different groups perceptions. Comput. Human Behav. 60, 514-524. doi: 10.1016/j.chb.2016.02.056

Strayer, J. F., Hart, J. B., and Bleiler-Baxter, S. K. (2016). Kick-starting discussions with the flipped classroom. Math. Teacher 109, 662-668. doi: 10.5951/mathteacher.109.9.0662

Sun, P., and Yuan, R. (2018). Understanding collaborative language learning in novice-level foreign language classrooms: perceptions of teachers and students. Interactive Learn. Environ. 26, 189-205. doi: 10.1080/10494820.2017.1285790

Suo, J., and Hou, X. (2017). A study on the motivational strategies in college English flipped classroom. Eng. Lang. Teach. 10, 62-67. doi: 10.5539/elt.v10n5p62

Wang, Y., L., Derakhshan, A., and Zhang, L. J. (2021). Researching and practicing positive psychology in second/foreign language learning and teaching: the past, current status and future directions. Front. Psychol. 12:731721. doi: $10.3389 /$ fpsyg.2021.731721

Wenwen, M. A. O., and Yuying, L. I. (2020). A study on English translation teaching based on flipping. Stud. Liter. Lang. 20, 138-141.

Xie, F., and Derakhshan, A. (2021). A conceptual review of positive teacher interpersonal communication behaviors in the instructional context. Front. Psychol. 12, 1-10. doi: 10.3389/fpsyg.2021.708490

Yanhui, C., and Yi, W. (2014). Flipped class model and its application to college English teaching. J. Inner Mongolia Univ. Fin. Econ. 11, 116-120.

$\mathrm{Yu}, \mathrm{H}$. (2017). "A study of the application of flipped classroom model in translation teaching to English majors," in 2017 3rd International Conference on Social Science and Higher Education (New York, NY: Atlantis Press), 507-509. doi: 10.2991/icsshe-17.2017.128

Yukun, C., and Aili, T. (2014). Introduction to MOOC and Flipped Classroom. Shanghai: East China Normal University Press.

Zainuddin, Z. (2018). Students' learning performance and perceived motivation in gamified flipped-class instruction. Comput. Educ. 126, 75-88. doi: 10.1016/j.compedu.2018.07.003

Zainuddin, Z., and Attaran, M. (2016). Malaysian students' perceptions of flipped classroom: a case study. Innov. Educ. Teach. Int. 53, 660-670. doi: 10.1080/14703297.2015.1102079

Zainuddin, Z., and Halili, S. H. (2016). Flipped classroom research and trends from different fields of study. Int. Rev. Res. Open Distrib. Learn. 17, 313-340. doi: 10.19173/irrodl.v17i3.2274

Zainuddin, Z., and Perera, C. J. (2019). Exploring students' competence, autonomy and relatedness in the flipped classroom pedagogical model. J. Further High. Educ. 43, 115-126. doi: 10.1080/0309877X.2017.1356916

Conflict of Interest: The author declares that the research was conducted in the absence of any commercial or financial relationships that could be construed as a potential conflict of interest.

Publisher's Note: All claims expressed in this article are solely those of the authors and do not necessarily represent those of their affiliated organizations, or those of the publisher, the editors and the reviewers. Any product that may be evaluated in this article, or claim that may be made by its manufacturer, is not guaranteed or endorsed by the publisher.

Copyright $(\odot 2021$ Wei. This is an open-access article distributed under the terms of the Creative Commons Attribution License (CC BY). The use, distribution or reproduction in other forums is permitted, provided the original author(s) and the copyright owner(s) are credited and that the original publication in this journal is cited, in accordance with accepted academic practice. No use, distribution or reproduction is permitted which does not comply with these terms. 